\title{
Specific Management Areas as a Function of Dendrometric Properties of Eucalyptus and Physical-Chemical Attributes in an Oxisol
}

\author{
Fernando S. Galindo ${ }^{1}$, Rafael Montanari ${ }^{1}$, Mayara M. Martins ${ }^{2}$, Flavia C. Meirelles ${ }^{3}$, Mariana G. Z. Ludkiewicz ${ }^{1}$, \\ Yane de F. da Silva ${ }^{4}$, Patrick L. F. dos Santos ${ }^{3}$, Vinicius M. Silva ${ }^{3} \&$ Valéria da S. Modenese ${ }^{3}$ \\ ${ }^{1}$ Department of Plant Health, Rural Engineering, and Soils, College of Engineering, Sao Paulo State University, \\ Ilha Solteira, SP, Brazil \\ ${ }^{2}$ School of Agriculture "Luiz de Queiroz”, São Paulo University, Piracicaba, SP, Brazil \\ ${ }^{3}$ Department of Plant Science, Food Technology and Social Economy, College of Engineering, Sao Paulo State \\ University, Ilha Solteira, SP, Brazil \\ ${ }^{4}$ Department of Rural Engineering, College of Agricultural and Veterinary Sciences, Sao Paulo State University, \\ Jaboticabal, SP, Brazil \\ Correspondence: Fernando S. Galindo, Department of Plant Health, Rural Engineering, and Soils, College of \\ Engineering, Sao Paulo State University, Ilha Solteira, State of Sao Paulo, Brazil. Tel: 55(18)-981-208-054. \\ E-mail: fs.galindo@yahoo.com.br
}

Received: February 26, 2018

Accepted: March 28, $2018 \quad$ Online Published: April 15, 2018

doi:10.5539/jas.v10n5p34

URL: https://doi.org/10.5539/jas.v10n5p34

\begin{abstract}
Eucalyptus cultivation has expanded considerably in Brazil, especially in regions where soils have low fertility, as in the Brazilian Cerrado (Brazilian Savannah). In order to achieve high yield, it is necessary to know the appropriate time and place to perform the soil management, and to assist in this decision-making process, mathematical and computational models has been used and are a promising alternative. The objective of this study was to model the influence of plant and soil physical-chemical attributes on Eucalyptus camaldulensis cultivation in an Oxisol (Latossolo Vermelho distrófico), with clayey texture with the purpose of demonstrating specific management areas closely associated with eucalyptus development. An experimental grid of approximately 2 hectares (ha) containing 40 sampling points were installed and later soil and plant attributes were collected for the determination of physical and chemical attributes in the $0-0.20 \mathrm{~m}$ and $0.20-0.40 \mathrm{~m}$ layers in Selvíria, MS, Brazil. The results were analyzed using classical and geostatistical statistics. The spatial dependence varied according to the physical attribute evaluated and the depth of sampling. In addition to the vertical variability, there was also horizontal variability between depths, since for the same attribute the range was different between the sampled layers.
\end{abstract}

Keywords: soil management, forest sustainability, forestry, geostatistics

\section{Introduction}

The cultivation of Eucalyptus spp. in Brazil has increased due to rapid growth, diversification in wood use and ease of adaptation to different soil and climatic conditions. This fact makes the productivity of commercial eucalyptus plantations quite variable (Lima et al., 2017a). According to the Brazilian Forestry Service (2016), the country obtains the best technologies in eucalyptus forestry, reaching average productivity of $60 \mathrm{~m}^{3} \mathrm{ha}^{-1}$ in seven-year rotations.

Because of its potential and diversity of use, Eucalyptus camaldulensis is a species of great economic interest, being one of the first cultivation that was planted successfully in regions outside the origin continent (Lima et al., 2010a). The literature has indicated that its main characteristics are given by the ability to grow well in relatively poor soils (frugal species), resistance to long periods of drought, tolerance to excessive rainfall, resistance to frost and production of hard, heavy and dark wood, when compared to the species E. grandis and E. globulus (Lima et al., 2010a). However, its growth can be influenced by some physical-chemical characteristics of soil, mainly in Brazilian Cerrado, which, among other factors, is commonly poor in nutrients and with high soil acidity (Toledo et al., 2015). 
Forestry enterprises have sought an efficiency of both planning and management processes involving practices of reforestation execution and demanded specific knowledge on the species cultivated as well as the site for their production (Lima et al., 2017b). However, the traditional methods used to assess both the development and the productivity of the forests is the measure of central tendency, which is generally average, in addition to a measure of dispersion, such as variance, without considering the affinities existing between surrounding samplings (Lima et al., 2017c). Therefore, with an increase in the necessity of further information on a production area, the use of accuracy instruments is it used applied to forestry (Pelissari et al., 2012).

In addition, highly weathered Cerrado soils have low fertility, low cation exchange capacity (CTC), high aluminum saturation and high acidity (Barbosa et al., 2012). Without correcting these soils, eucalyptus, like other crops, has its development impaired, since it finds impediments to the growth of the root system, responsible for the absorption of water and nutrients necessary for the crop cycle, thus affecting productivity (Costa et al., 2015). Lima et al. (2013) showed that the physical and chemical attributes of the soil, as well as those related to plants, present spatial variability and that the distance between the samples should be taken into account in the study of these attributes, as recommended by geostatistics. Knowing the spatial distribution of the granulometric fractions allows to analyze correctly the availability of the chemical elements in the soil, as reported by Silva et al. (2010).

The new technologies used in the agrarian sector have improved the determination of the spatial and temporal variability of certain attributes, from the mapping even in their correlations, analyzing the distance between the samples in order to represent with more precision the factors that affect the crops profitability (Lima et al., 2010a; Lima et al., 2010b).

In this context, the combination of forestry and geostatistics aims to analyze the spatial dependence of georeferenced data, which are adjusted in semivariograms according to the distances between the observations. From the semivariogram, kriging maps can be create for each attribute searched for, soil and plant, which represents the spatial variability of the data and then obtain the specific areas of soil management for the attribute (Carvalho et al., 2012).

In view of above, the objective of this study was to analyze the linear and spatial correlations of individual development of Eucalyptus camaldulensis trees as a function of plant attributes and soil physical-chemical in an Oxisol, in order to show specific management areas closely associated to the development of Eucalyptus, assisting in soil management and decision making in a sustainable manner to the environment.

\section{Methods}

\subsection{Field Sites and Material Description}

The study was carried out during the 2016 year at the Education and Research Farm of São Paulo State University $\left(20^{\circ} 20^{\prime} 53^{\prime \prime} \mathrm{S}\right.$ and $\left.51^{\circ} 24^{\prime} 02^{\prime \prime} \mathrm{W}\right)$ located in the municipality of Selvíria, MS, Brazil, with an altitude of $335 \mathrm{~m}$ (Figure 1). The soil was classified as typical Oxisol, with clayey texture (Latossolo Vermelho distrófico típico) (Santos et al., 2013). According to the Köppen classification, the climate of the region is Aw, tropical climate with dry winter season, with an average annual rainfall of $1,313 \mathrm{~mm}$, with maximum annual temperature of $31{ }^{\circ} \mathrm{C}$ and minimum annual temperature of $19^{\circ} \mathrm{C}$ (Galindo et al., 2016 ), annual relative air humidity between $70 \%$ and $80 \%$ (Centurion, 1982). Precipitation, and maximum, average, and minimum temperatures recorded during the experimental year period are shown in Figure 2. 


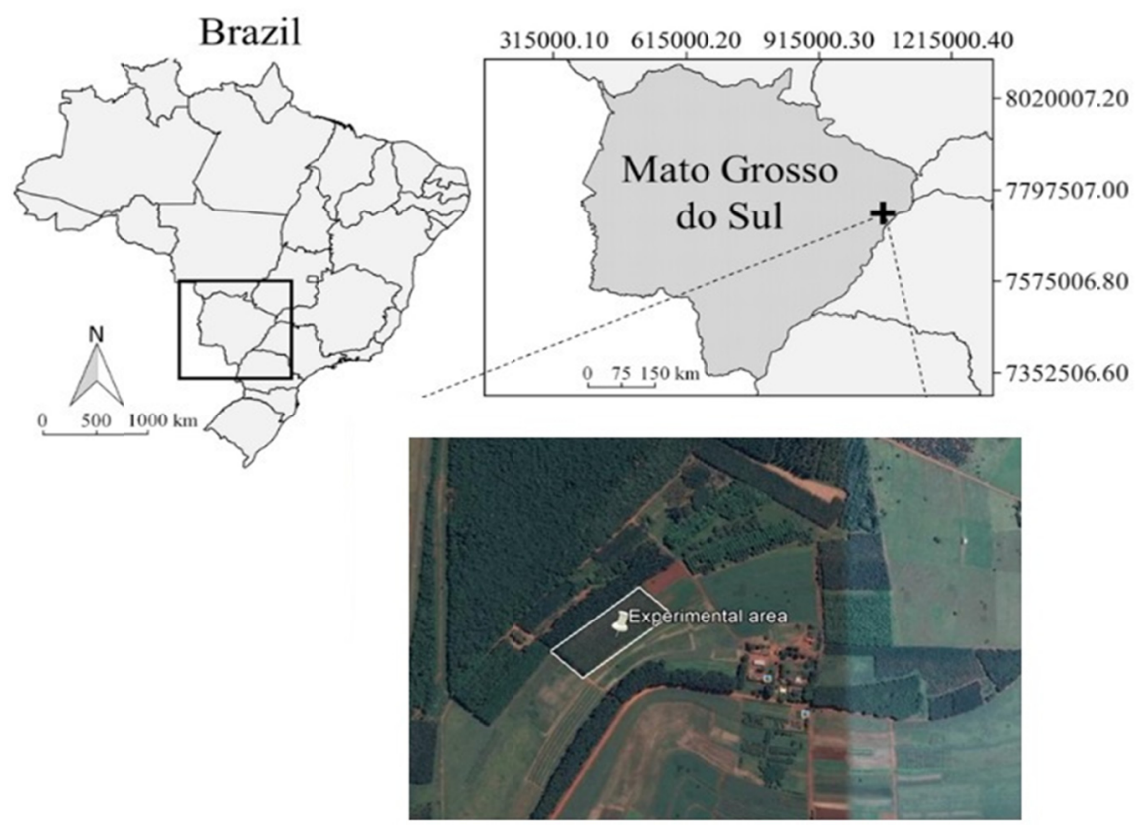

Figure 1. Study area at the Selvíria, Mato Grosso do Sul, Brazil $\left(20^{\circ} 22^{\prime} \mathrm{S}, 51^{\circ} 22^{\prime} \mathrm{W}\right.$, altitude of $\left.335 \mathrm{~m}\right)$

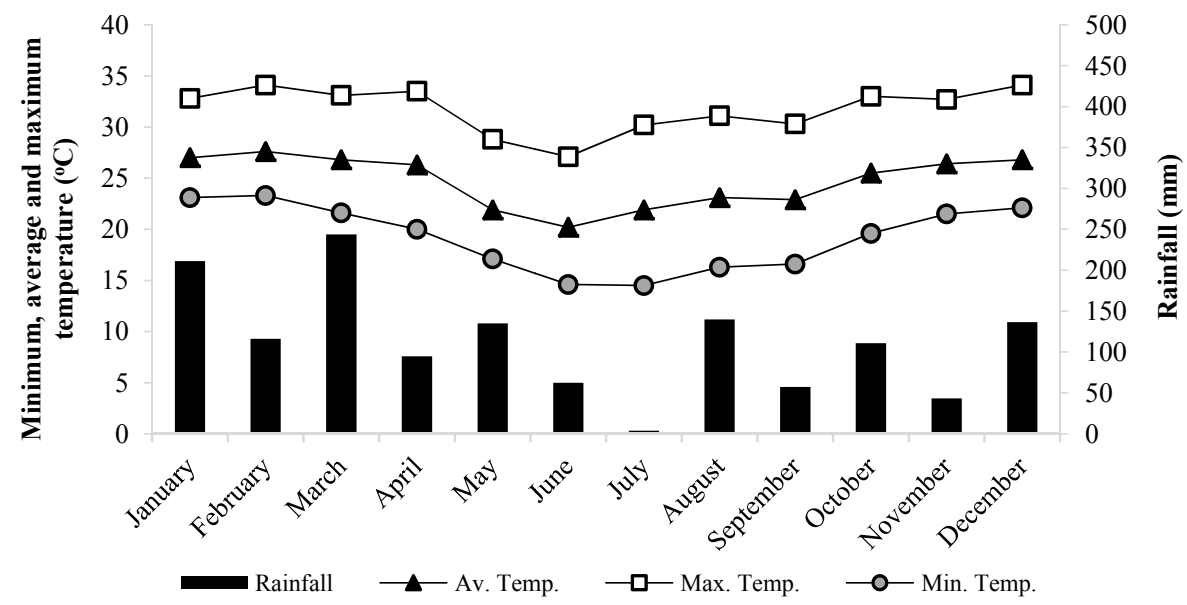

Figure 2. Rainfall, and maximum, average, and minimum temperature obtained from the weather station located on the Education and Research Farm of FE/UNESP during eucalyptus research in the year of 2016

\subsection{Experimental Design and Evaluations}

The test-plant was Eucalyptus camaldulensis, with field installed on 10/10/2008, and spacing of $3.0 \mathrm{~m} \times 1.8 \mathrm{~m}$. Sampling points were determined by cartesian coordinates in the planted area with Eucalyptus. An experimental mesh with 40 points was performed. The transects were spaced $9 \mathrm{~m}$ apart, with sample points in the form of $9 \times$ $9 \mathrm{~m}$.

The following evaluations were carried out: Plant height (ALT); Diameter at breast height (DAP); soil penetration resistance (RP); gravimetric humidity (UG); volumetric humidity (UV); soil density (DS); particle density (DP) and total porosity (PT), soil organic matter (MO); hydrogen potential (pH) in $\mathrm{CaCl}_{2}$, and acidity potential (ACPOT), collected at two depths: 0.0-0.2 and 0.2-0.4 m. Therefore, 14 attributes were analyzed: ALT, DAP, RP1, RP2, UG1, UG2, UV1, UV2, DS1, DS2, DP1, DP2, PT1, PT2, pH1, pH2, MO1, MO2, ACPOT1, ACPOT2. 
Plant and soil attributes were individually collected around each sampling point. The mechanical resistance was evaluated with the impact penetrometer (Stolf, 1991) and calculated according to the following equation:

$$
\mathrm{RP}=\{\{5.581+6.891 \cdot\{[\mathrm{N} /(\mathrm{P}-\mathrm{A})] \cdot 10\}\} \cdot 0.0981
$$

where, RP is the mechanical resistance of the soil to penetration $(\mathrm{MPa})$; $\mathrm{N}$, the number of impacts made with the penetrometer hammer to obtain the reading; and $\mathrm{A}$ and $\mathrm{P}$, the readings before and after the impacts $(\mathrm{cm})$.

The $\mathrm{pH}$ was determined potentiometrically in $0.01 \mathrm{~mol} \mathrm{~L}^{-1} \mathrm{CaCl}_{2}$ solution, and the organic $\mathrm{C}$ by the wet combustion method, via colorimetric, the organic matter content of the soil being calculated by the following equation (Raij et al., 2001):

$$
\mathrm{MO}=\mathrm{C} \cdot 17.24
$$

where, $\mathrm{MO}$ is the organic matter content $\left(\mathrm{g} \mathrm{dm}^{-3}\right)$ and $\mathrm{C}$ is the carbon content $\left(\mathrm{g} \mathrm{dm}^{-3}\right)$.

All analyzes were performed at the Laboratory of Physics and Soil Chemistry of the Faculty of Engineering of Ilha Solteira, UNESP. The attributes of the evaluated plant in the field were diameter at breast height, in centimeters (DAP), and the plant height, in meters (ALT). The devices used were, respectively, a measure tape and a dendrometer vertex.

For the determination of DS, undisturbed samples were collected using the volumetric ring method. Gravimetric humidity was obtained using an analytical balance and for the volumetric humidity the ring volume was taken into account. The volumetric flask method was used to determine the particle density $\left(\mathrm{kg} \mathrm{dm}^{-3}\right)$, and for the total porosity the bulk density and the actual density were used Embrapa (1997).

\subsection{Analytical Procedures}

Laboratory analyzes were performed at the Soil Physical Analysis Laboratory of the Faculty of Engineering of Ilha Solteira, UNESP. Descriptive analysis of all attributes was performed using the SAS statistical program (Schlotzhaver \& Littell, 1997). Thus, the mean, median, minimum and maximum values, standard deviation, coefficient of variation, kurtosis, asymmetry and frequency distribution were obtained. It was also found outliers that were properly disposed.

For the normality hypothesis test, we used the statistics of Shapiro and Wilk (1965) at 5\% probability. In addition, the correlation matrix was made in order to present the regression analyzes, two for two, between the attributes. From this analysis, we selected the attributes that presented the highest linear correlation, to perform the cross-semivariogram and the cokriging. The spatial dependence, for each isolated attribute, was verified using the simple semivariogram.

Since the attributes that presented spatial interdependence, the cross-semivariograms were realized, with the aid of the package Gamma Design Software (Robertson, 2004). Some factors were taken into account to adjust the simple and crossed semivariograms, as the smaller sum of the squares of the deviations (SQD); higher determination coefficient $\left(\mathrm{R}^{2}\right)$ and higher assessed spatial dependence (ADE).

Were related the nugget effect $\left(C_{0}\right)$, range $\left(A_{o}\right)$ and the threshold $\left(C_{o}+C\right)$ for each attribute studied. To determine the spatial dependence estimator, the equation $\mathrm{ADE}=\left[\mathrm{C} /\left(\mathrm{C}+\mathrm{C}_{\mathrm{o}}\right)\right] \cdot 100$ was used, in which $\mathrm{ADE}$ is the spatial dependence estimator; $\mathrm{C}$ is the structural variance and $\mathrm{C}+\mathrm{C}_{\mathrm{o}}$ is the threshold, respectively.

Cross-validation is used to estimate alternative models of both simple and crossed semivariograms. Thus, the real values obtained are eliminated and values are estimated in the spatial domain, being able to obtain graphs relating the estimated and observed values. Thus, the adjustment is determined by the correlation coefficient (r), obtained by summing the squares of the deviations. Therefore, the regression coefficient equal to 1 would provide a perfect fit, with the linear coefficient being zero and the angular value equal to 1 (Robertson, 2004). The kriging and cokriging maps were obtained to evaluate the spatial dependence and interdependence of the attributes studied.

\section{Results and Discussion}

\subsection{Descriptive Analysis}

According to Pimentel Gomes and Garcia (2002), the variability of an attribute is classified according to the magnitude of the CV (coefficient of variation). In this way, Table 1 presents the descriptive analysis of the studied attributes. 
Table 1. Descriptive analysis of eucalyptus production components and attributes of an Oxisol

\begin{tabular}{|c|c|c|c|c|c|c|c|c|c|c|}
\hline \multirow{3}{*}{ Attribute $^{(a)}$} & \multicolumn{10}{|c|}{ Descriptive statistical measures } \\
\hline & \multirow{2}{*}{ Mean } & \multirow{2}{*}{ Median } & \multicolumn{2}{|c|}{ Value } & \multirow{2}{*}{$\begin{array}{l}\text { Standart } \\
\text { deviation }\end{array}$} & \multicolumn{3}{|c|}{ Coefficient } & \multicolumn{2}{|c|}{ Probability of the test ${ }^{(b)}$} \\
\hline & & & Minimum & Maximum & & Variation $(\%)$ & Kurtosis & Asymmetry & $\operatorname{Pr}<w$ & DF \\
\hline \multicolumn{11}{|l|}{ Plant attributes } \\
\hline $\operatorname{ALT}(\mathrm{m})$ & 17.8 & 18.3 & 10.2 & 27.0 & 4.140 & 23.3 & -0.882 & 0.008 & 0.250 & NO \\
\hline $\mathrm{DAP}(\mathrm{cm})$ & 12.8 & 13.1 & 7.5 & 18.2 & 2.931 & 22.9 & -0.810 & -0.018 & 0.404 & NO \\
\hline \multicolumn{11}{|l|}{ Soil physical attributes } \\
\hline RP1 (MPa) & 4.533 & 3.857 & 1.649 & 10.687 & 2.416 & 53.3 & 0.420 & 1.084 & 0.001 & IN \\
\hline RP2 (MPa) & 6.480 & 6.100 & 1.474 & 13.471 & 3.090 & 48.4 & -0.165 & 0.740 & 0.011 & IN \\
\hline UG1 $\left(\mathrm{kg} \mathrm{kg}^{-1}\right)$ & 0.122 & 0.122 & 0.109 & 0.149 & 0.009 & 7.2 & 1.356 & 0.977 & 0.033 & $\mathrm{TN}$ \\
\hline $\mathrm{UG} 2\left(\mathrm{~kg} \mathrm{~kg}^{-1}\right)$ & 0.119 & 0.118 & 0.106 & 0.137 & 0.006 & 5.4 & 1.600 & 0.899 & 0.015 & IN \\
\hline $\mathrm{UV} 1\left(\mathrm{~m}^{3} \mathrm{~m}^{-3}\right)$ & 0.140 & 0.142 & 0.075 & 0.213 & 0.026 & 18.3 & 1.974 & -0.042 & 0.026 & $\mathrm{TN}$ \\
\hline $\mathrm{UV} 2\left(\mathrm{~m}^{3} \mathrm{~m}^{-3}\right)$ & 0.153 & 0.152 & 0.121 & 0.208 & 0.016 & 10.8 & 1.987 & 0.880 & 0.090 & NO \\
\hline DS1 $\left(\mathrm{kg} \mathrm{dm}^{-3}\right)$ & 1.164 & 1.155 & 0.776 & 1.364 & 0.116 & 9.9 & 1.893 & -0.807 & 0.074 & NO \\
\hline DS2 $\left(\mathrm{kg} \mathrm{dm}^{-3}\right)$ & 1.278 & 1.265 & 0.976 & 1.583 & 0.117 & 9.2 & 0.960 & 0.395 & 0.228 & NO \\
\hline DP1 $\left(\mathrm{kg} \mathrm{dm}^{-3}\right)$ & 2.635 & 2.590 & 2.378 & 3.066 & 0.152 & 5.8 & 1.520 & 1.106 & 0.003 & IN \\
\hline $\mathrm{DP} 2\left(\mathrm{~kg} \mathrm{dm}^{-3}\right)$ & 2.572 & 2.564 & 2.332 & 2.798 & 0.096 & 3.7 & 0.949 & 0.139 & 0.134 & NO \\
\hline PT1 $\left(\mathrm{m}^{3} \mathrm{~m}^{-3}\right)$ & 0.567 & 0.560 & 0.462 & 0.744 & 0.061 & 10.7 & 1.646 & 0.924 & 0.038 & $\mathrm{TN}$ \\
\hline PT2 $\left(\mathrm{m}^{3} \mathrm{~m}^{-3}\right)$ & 0.504 & 0.500 & 0.387 & 0.611 & 0.046 & 9.1 & 0.680 & -0.194 & 0.644 & NO \\
\hline \multicolumn{11}{|l|}{ Soil chemical attributes } \\
\hline $\operatorname{MO1}\left(\mathrm{g} \mathrm{dm}^{-3}\right)$ & 19.2 & 18.0 & 12 & 32 & 5.070 & 26.36 & 0.829 & 1.206 & 0.0003 & IN \\
\hline $\operatorname{MO} 2\left(\mathrm{~g} \mathrm{dm}^{-3}\right)$ & 13.6 & 13.0 & 11 & 20 & 1.945 & 14.30 & 2.045 & 1.435 & $<0.0001$ & IN \\
\hline $\mathrm{pH} 1\left(\mathrm{CaCl}_{2}\right)$ & 4.2 & 4.2 & 3.8 & 4.8 & 0.284 & 6.71 & -0.677 & 0.542 & 0.018 & IN \\
\hline $\mathrm{pH} 2\left(\mathrm{CaCl}_{2}\right)$ & 4.0 & 4.0 & 3.9 & 4.7 & 0.153 & 3.77 & 6.735 & 2.118 & $<0.0001$ & IN \\
\hline $\operatorname{ACPOT} 1\left(\mathrm{mmol}_{\mathrm{c}} \mathrm{dm}^{-3}\right)$ & 5.8 & 5.8 & 5.4 & 6.2 & 0.190 & 3.27 & -0.214 & -0.178 & 0.285 & NO \\
\hline ACРОT2 $\left(\mathrm{mmol}_{\mathrm{c}} \mathrm{dm}^{-3}\right)$ & 5.7 & 5.8 & 5.5 & 6.1 & 0.104 & 1.80 & 2.138 & 0.261 & 0.0008 & IN \\
\hline
\end{tabular}

Note. ${ }^{\text {(a) }}$ ALT $=$ Eucalyptus plant height; DAP $=$ Diameter at breast height; RP, UG, UV, DS, DP, PT, MO, $\mathrm{pH}$ and ACPOT 1 and 2, are respectively the penetration resistance, gravimetric humidity, volumetric humidity, soil density, particle density, total porosity, organic matter, hydrogen potential and acidity potential, collected in the soil layers; ${ }^{(b)} \mathrm{DF}=$ frequency distribution, being NO, TN and IN respectively of normal type, tending to normal and indeterminate.

The plant attributes plant height (ALT) and diameter at breast height (DAP) presented a high variability with CV $23.3 \%$ and $22.9 \%$ respectively (Table 1), above that reported by Rosa Filho et al. (2011), who had found median value of $14.4 \%$ when assessing the productivity and attributes of the soil in a Eucalyptus urophylla forest site and Lima et al. (2010), who verified mean values of variation coefficient for the ALT of $12.0 \%$. However, similar results was observed by Lima et al., (2017b) who verified mean values of variation coefficient for the ALT and DAP 18.23 and $23.45 \%$, respectively.

The physical attributes of soil that presented low variability were gravimetric humidity (UG1 and UG2), soil density (DS1 and DS2), particle density (DP1 and DP2) and total porosity (PT2) with respective values; 7.2\%, $5.4 \%, 9.9 \%, 9.2 \%, 5.8 \%, 3.7 \%$ and $9.1 \%$ (Table 1 ). The volumetric humidity (UV1 and UV2) and total porosity (PT1) showed CV following order, 18.3\%, 10.8\% and 10.7\% (Table 1), confirming Lima et al., (2017a), who verified mean variations in CV for soil physical attributes between 1.0 and $18.9 \%$. While the penetration resistance attributes (RP1 and RP2) presented very high variability, with CV 53.3\% and 48.4\% respectively (Table 1), corroborating with the results observed by Carvalho et al. (2012).

The variation coefficient should be used as a parameter to validate the mean values found since, according to Pimentel-Gomes and Garcia (2002), a variation coefficient above $30 \%$ reveals that the average has low significance, and values above $60 \%$ reflect a very heterogeneous set of data canceling the confidence of the average. However, if below $30 \%$, data are homogeneous and the average is significant and able to be used as representative for the data obtained. Some authors relate the very high variability associated with the distribution of the arrangement of some nutrients, thus increasing the heterogeneity of these parameters (Corá et al., 2004).

For the chemical attributes of the soil, with exception of the organic matter (MO1 and MO2), which presented high and medium variability with respect to CV (26.36\% and 14.30\%) (Table 1), the other attributes analyzed; 
hydrogen potential (pH1 and $\mathrm{pH} 2$ ), and potential acidity (ACPOT1 and ACPOT2) had low variability with CV respectively $6.71 \% 3.77 \%, 3.27 \%$ and $1.80 \%$ (Table 1). According to Arthur et al. (2014), the variations of soil chemical attributes are related to alterations caused by irregular fertilizations and limestones, and due to the high heterogeneity around the average among the chemical attributes in the evaluated area. This heterogeneity can have several causes, among them, the process of soil formation and accumulation and distribution of soil particles as a function of the shape of the relief and the flow of water in the area.

Plant attributes (ALT and DAP) presented normal frequency distribution, with positive asymmetry coefficients for ALT (0.008) and negative for DAP (-0.018) (Table 1). The kurtosis coefficient was negative for both -0.882 and -0.810 respectively (Table 1 ). As well as the attributes related to soil physics, with normal frequency for UV2, DS1, DS2, DP2 and PT2, with both positive asymmetry coefficient ranging from 0.169 to 0.880 and negative ranging from -0.807 to -0.194 (Table 1). The kurtosis coefficients were positive, varying from 0.680 to 1.987 (Table 1).

The attributes RP1, RP2, UG1, UG2, DP1, as well as all chemical attributes (MO1, MO2, pH1, pH2, ACPOT2) except for ACPOT1 (normal rate) had indeterminate distribution (Table 1). UG1, UV1, PT1 presented a tendency to normal, with positive asymmetry values of 0.924 to 0.977 and negative values of -0.042 , and positive kurtosis values ranging from 1.356 to 1.974 (Table 1).

According to Dalchiavon et al. (2011), if a variable has a normal frequency distribution (NO), the measure of central tendency most appropriate to represent it should be the mean, while if its frequency distribution tends to normal (TN), or indeterminate (IN), will be better represented by the median, so the average values found for ALT and DAP were 17.8 and $12.8 \mathrm{~cm}$, respectively. For UV2, DS1 and DS2, DP2, PT2 and ACPOT1 the mean values were $0.153 \mathrm{~m}^{3} \mathrm{~m}^{-3}, 1.164$ and $1.278 \mathrm{~kg} \mathrm{dm}^{-3}, 2.572 \mathrm{~kg} \mathrm{dm}^{-3}, 0.504 \mathrm{~m}^{3} \mathrm{~m}^{-3}$ and $5.8 \mathrm{mmol}_{\mathrm{c}} \mathrm{dm}^{-3}$, respectively (Table 1). For the other attributes the median values were considered; (MPa), RP1 and RP2 (3.857 and $6.100 \mathrm{MPa}), \mathrm{U} 1$ and UG2 (0.122 and $\left.0.118 \mathrm{~kg} \mathrm{~kg}^{-1}\right)$, UV1 $\left(0.142 \mathrm{~m}^{3} \mathrm{~m}^{-3}\right)$, DP1 $\left(2.590 \mathrm{~kg} \mathrm{dm}^{-3}\right)$, PT1 $(0.560$ $\left.\mathrm{m}^{3} \mathrm{~m}^{-3}\right) \mathrm{MO} 1$ and MO2 $\left(18.0\right.$ and $\left.13.0 \mathrm{~g} \mathrm{dm}^{-3}\right), \mathrm{pH} 1$ and $\mathrm{pH} 2\left(4.2\right.$ and $\left.4.0 \mathrm{CaCl}_{2}\right)$ and ACPOT2 $\left(5.7 \mathrm{mmol}_{\mathrm{c}} \mathrm{dm}^{-3}\right)$ (Table 1).

For the plant attribute ALT, mean values were below those verified by Rosa Filho et al. (2011), with mean ALT of $31 \mathrm{~m}$ in Eucalyptus urophylla and LIMA et al. (2010), who reported for Eucalyptus camaldulensis, under similar conditions to the present study ALT of $24 \mathrm{~m}$, however, the values obtained were higher than those reported by Carvalho et al. (2012) for Eucalyptus camaldulensis also in an Oxisol with clayey texture in Cerrado condition, with average ALT of $9.2 \mathrm{~m}$. Regarding DAP, the values found are within the range suitable for Eucalyptus spp. in the age range of the culture at the time of analysis ( 8 years), with values between 12 and 14 cm (Simões et al., 1980; Anjos \& Fontes, 2017).

Regarding the soil physical results obtained, for soil density, the normal values for clayey soils vary from 0.9 to $1.7 \mathrm{~kg} \mathrm{dm}^{-3}$ (Costa et al., 2014). DS values associated with the compaction state with high probability of presenting restriction risks to root growth are around $1.45 \mathrm{~kg} \mathrm{dm}^{-3}$ for clay soils (Costa et al., 2014), so the verified soil density in the present work was adequate in the layers of 0.0-0.2 and 0.2-0.4 m.

With regard to DP, this variable expresses the relationship between the amount of dry soil mass per unit volume of soil solid; therefore, does not include soil porosity and does not vary with soil management (Costa et al., 2014), being therefore a characteristic dependent primarily on the chemical composition and mineralogical composition of the soil. The components that predominate in mineral soils present values of DP of about $2.65 \mathrm{~kg}$ $\mathrm{dm}^{-3}$, except when it has organic matter content or high Fe and Al oxides (Costa et al., 2014), as verified in the present work.

The total pores of soils are constituted by the macro and micropores, so that the increase of one will reduce the percentage of the other. In the study of soil density, aggregation and porosity in areas of Cerrado conversion in the Pinus forest, Wendling et al. (2012) verified average total porosity values of $0.6 \mathrm{~m}^{3} \mathrm{~m}^{-3}$, close to those observed in the present study.

As for the penetration resistance, the mean values obtained were very high (Arshad et al., 1996) and were well above the critical limit of 2.5 MPa recommended by Camargo and Alleoni (1997), and Souza et al. (2006) and Marasca et al. (2011), who recommend an acceptable range between 1.5 and $3.0 \mathrm{MPa}$, indicating that the eucalyptus plants found physical limitations to the growth of the root system. However, it should be considered that the penetration resistance has a potential relation with soil moisture (Busscher et al., 1997; Silveira et al., 2010), which may explain the values found for the amplitude and the coefficient of variation, considering that small changes in the water content determine large variations in the dependent quantity, that is, in the resistance to penetration. 
Compaction is a structural alteration that promotes the reorganization of the particles and their aggregates, being able to limit adsorption, gas exchange, nutrient absorption, infiltration and redistribution of water, delay in the emergence of seedlings and impairment of root and shoot development, resulting in decreases in crop productivity (Stone et al., 2002; Modolo et al., 2008). The physical attribute adopted as an indication of compaction has been the soil resistance to penetration, because it has direct relationships with the development of the plants and because it is more efficient in the identification of compaction states compared to the soil density (Silva et al., 2003), in this way, the soil could be considered as compacted for the cultivation of eucalyptus.

The soil pH was very low, providing high acidity in the soil, according to Raij et al. (1997), as well as low M.O., characteristic of Cerrado soils (Marchini et al., 2015). Thus, from the chemical point of view, the limiting factor for the development of the eucalyptus crop would be $\mathrm{pH}$, indirectly providing a high $\mathrm{Al}$ content in solution, which influences the development of the root system, and consequently in the absorption of water and nutrients, with reflection on aerial part development and crop productivity.

\subsection{Correlation Analysis}

Through the study of the Pearson correlation (Table 2), it was possible to observe positive and negative correlations between the attributes of eucalyptus and physical and chemical of soil.

The correlation between the attributes was positive for ALT $\times$ DAP $\left(r=0.717^{* *}\right)$, UV1 $\times$ DP1 $\left(r=0.358^{*}\right)$, MO1 $\times$ PH1 $\left(0.754^{* *}\right)$, MO2 $\times$ PH2 $\left(0.609^{* *}\right)$ and PT2 $\times$ ACPOT2 $\left(0.326^{*}\right)$ (Table 2, Figures 3 and 4), demonstrating that DAP is height dependent, that is, with eucalyptus height growth there is an increase in DAP, corroborating with Lima et al. (2017b), and further, that the particle density increases with increasing volumetric humidity in the 0.0-0.2 m layer, $\mathrm{pH}$ increases with increasing M.O. in the 0.0-0.2 and 0.2-0.4 m layers and that the total porosity increases with the increase in the potential acidity in the $0.2-0.4 \mathrm{~m}$ layer.

The correlation between attributes was negative for DAP $\times$ UV1 $\left(r=-0.338^{*}\right), \mathrm{RP} 1 \times \mathrm{MO} 1\left(\mathrm{r}=-0.313^{*}\right)$ and DP1-MO1 $\left(r=-0.364^{*}\right)$ (Table 2, Figures 3 and 4). showing that the higher is DAP, lower is the volumetric humidity in the 0.0-0.2 m layer, possibly due to the development of the root system, justifying the increase in diameter at breast height, and that this way increase the absorption of water and nutrients, thus reducing the volumetric humidity, and higher is the MO content, lower is the penetration resistance and the density of particles in the 0.0-0.2 m layer.

With the predominance of the Oxisols in Cerrado, the soils are strongly weathered and characterized by low natural fertility (Figuereido et al., 2008). Organic matter is fundamental to raise cation exchange capacity and, consequently, favor nutrient cycling, avoid sudden changes in $\mathrm{pH}$ and maintain a good aggregation of soil particles (Silva \& Resck, 1997). The importance of organic matter in soils is comprehensive. Its performance is as much in the improvement of the physical conditions, as in the aeration, in the greater retention and storage of water, as in the chemical and physical-chemical properties, in the nutrient supply to the plants and in the greater cationic exchange capacity of the soil, besides providing a suitable environment for the establishment and activity of the microbiota (Figueiredo et al., 2008; Silva et al., 2014). Pearson's linear correlation results evidenced the positive influence of the increase in M.O. in the physical properties of the soil RP and DP, besides positively influencing the $\mathrm{pH}$ of the soil, which would culminate in greater availability of nutrients, since the average $\mathrm{pH}$ obtained in the present study was in the range between 4.0 and 4.2 in $\mathrm{CaCl}_{2}$, and according to Silva et al. (2016), from the nutritional point of view, the adequate range is between 5.6 and 6.2 in $\mathrm{CaCl}_{2}$, culminating in greater availability of nutrients for the eucalyptus crop.

Still with respect to M.O., it was expected that $\mathrm{pH}$ reduction with increasing M.O. due to the release of organic acids in the decomposition process of M.O. (Pavinato et al., 2008), however, this result was not verified possibly due to M.O. have not yet presented total decomposition, due to the high $\mathrm{C} / \mathrm{N}$ ratio and high levels of lignin and polyphenols (Pulrolnick et al., 2009), resulting in slower decomposition. 
Table 2. Pearson's linear correlation of eucalyptus production components and attributes of an Oxisol

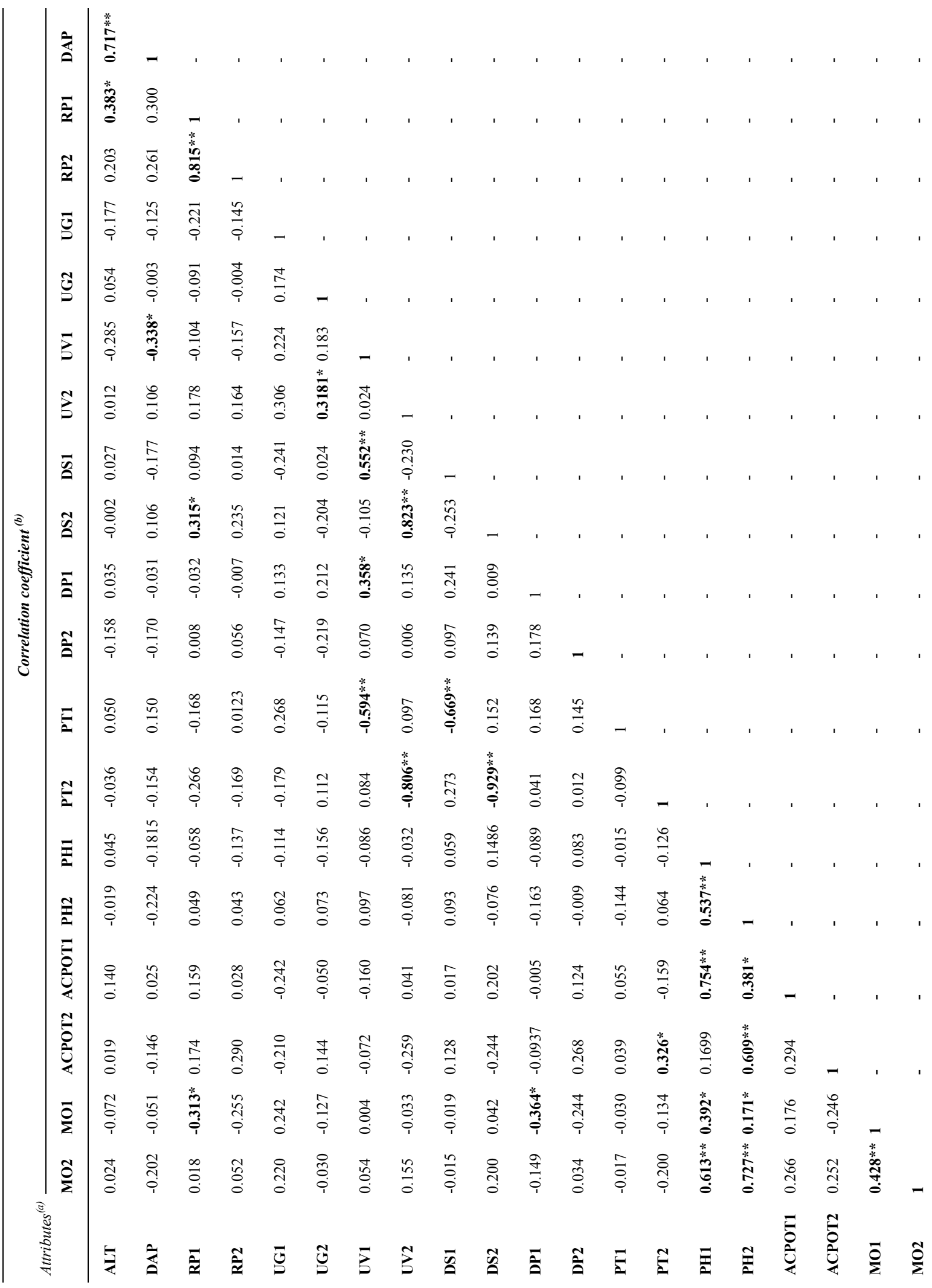

Note. ${ }^{(\mathrm{a})} \mathrm{ALT}=$ Eucalyptus plant height; DAP $=$ Diameter at breast height; RP, UG, UV, DS, DP, PT, MO, pH and ACPOT 1 and 2, are respectively the penetration resistance, gravimetric humidity, volumetric humidity, soil density, particle density, total porosity, organic matter, hydrogen potential and acidity potential, collected in the soil layers; ${ }^{(b)}$ Pearson's linear correlation coefficient. ** significant at $\mathrm{p}<0.01 ; *$ significant at $0.01<\mathrm{p}<0.05$. 

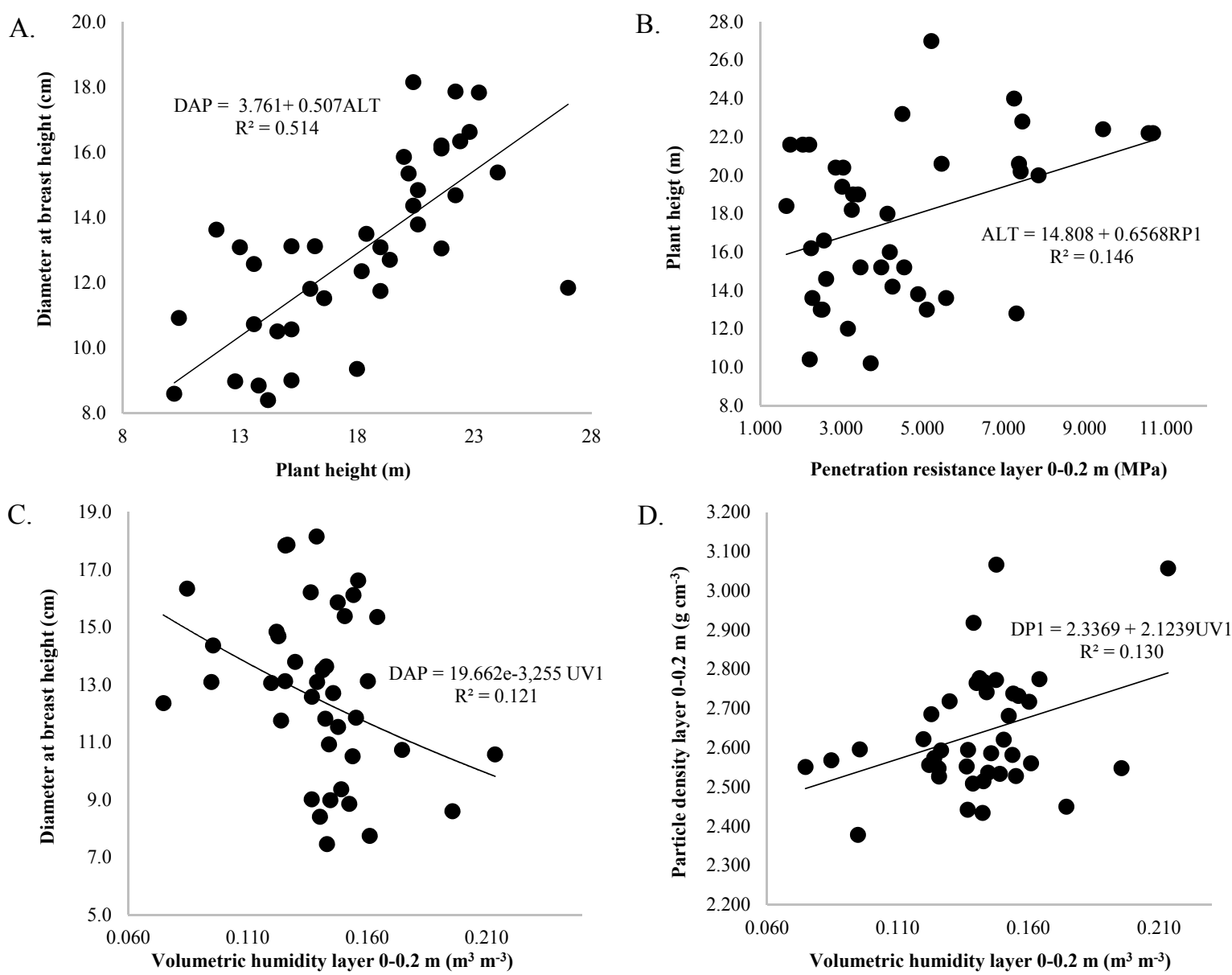

Figure 3. Regression graphs of the correlation between a) ALT $\times$ DAP; b) RP1 $\times$ ALT; c) UV1 $\times$ DAP; and d) $\mathrm{UV} 1 \times \mathrm{DP} 1$ 
A

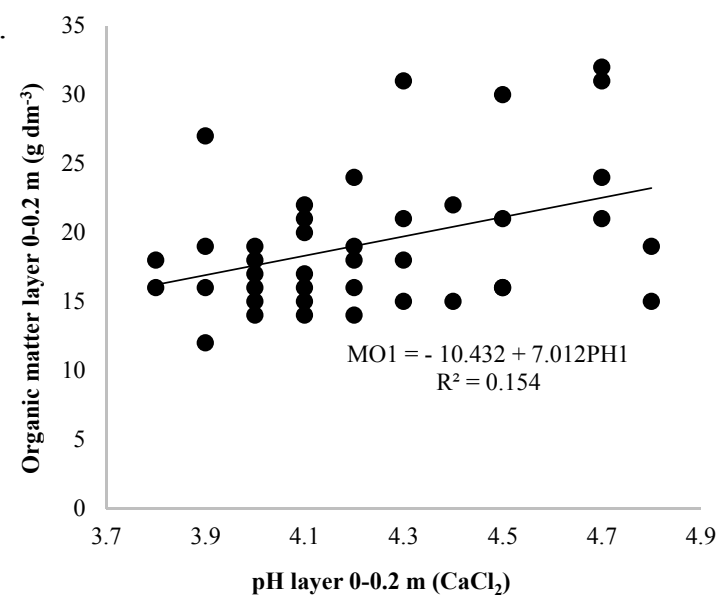

C.

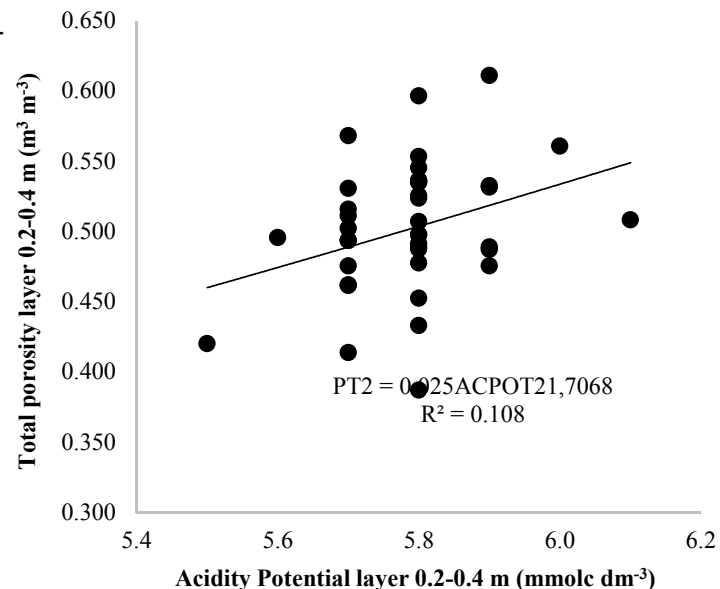

B.

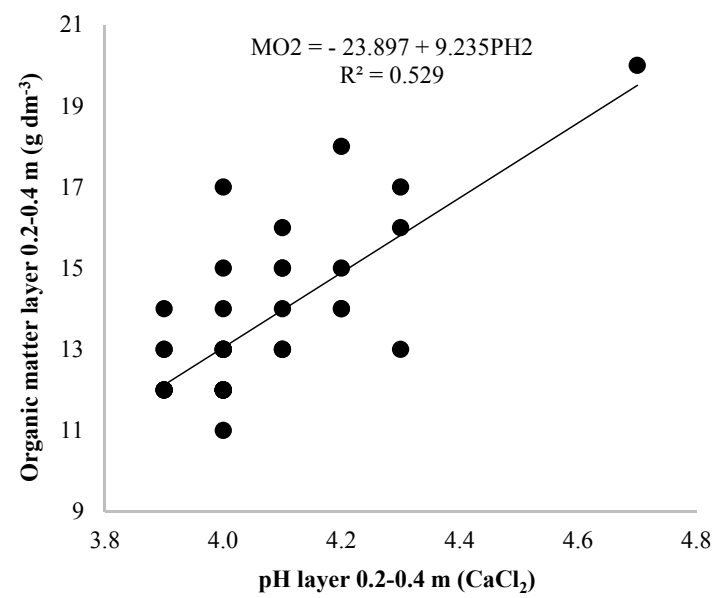

D.

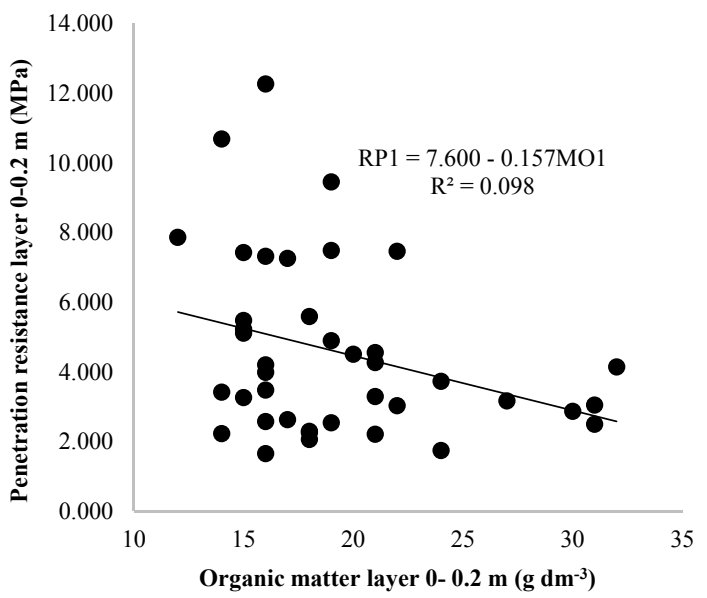

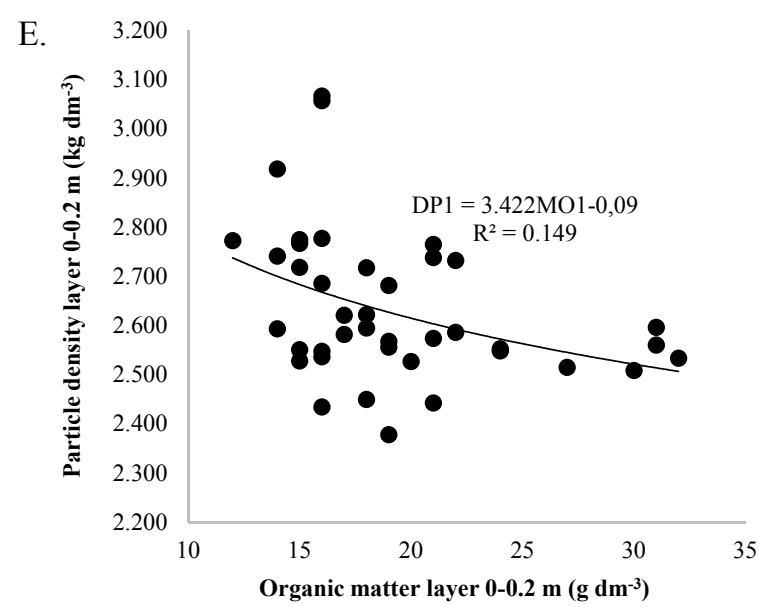

Figure 4. Regression graphs of the correlation between a) $\mathrm{pH} 1 \times \mathrm{MO} 1$; b) $\mathrm{pH} 2 \times \mathrm{MO}$; c) ACPOT2 $\times$ PT2; d)

$$
\mathrm{MO} 1 \times \mathrm{RP} 1 \text {; and e) } \mathrm{MO} 1 \times \mathrm{DP} 1
$$

\subsection{Geostatistical Analysis}

In Table 3 and Figure 5 are presented the parameters of the simple semivariograms for the attributes of plant and soil. The attributes that presented spatial dependence were DP1, DP2, DS1, DS2, UV1 and UG1 (Table 3 and Figure 5). All the others attributes did not presented spatial dependence. The lack of dependence is an indication that the value of semivariance is equal to the threshold, for any distance value. The total absence of spatial dependence is called a pure nugget effect, that is, the range (A0) of the data is smaller than the smaller spacing between collected samples. For these data, we have a completely random spatial distribution and the only applicable statistic is the classical statistics (Vieira, 2000). 
The pure nugget effect indicates that the spatial distribution of the attribute in the study area is homogeneous, random or the sampling mesh used does not have enough points to detect the dependence that, if it exists, will be manifested at distances smaller than the smaller spacing between samples (Guimarães, 2004). In the present study, the most probable cause of the spatial homogeneity observed may be associated to the Oxisol, whose class presents an advanced process of soil weathering and stability in its formation process.

Regarding the performance of the semivariograms, the highest spatial determination coefficient $\left(\mathrm{r}^{2}\right)$ observed for the model adjustment was 0.855 in the spatial dependence modeling for the DP2 and the lowest coefficient was 0.121 in the modeling of the UV1 spatial dependence (Table 3 and Figure 5). All models were selected after cross-validation analysis. The theoretical model that presented the best fit for the empirical semivariance of soil chemical attributes was the exponential followed by the spherical.

According to Bottega et al. (2013), when semivariograms are presented as spherical and exponential, they present simultaneously low and medium continuity of spatial variability. However, the Gaussian model is a high continuation of spatial variability. These adjustments can be explained by the physico-chemical changes made in the soil, mainly by the chemical attributes that change due to the correction and fertilization practices. Thus, MO1 was the attribute of better semivariographic adjustment with a spatial dependency evaluator (ADE) of $67.1 \%$, presenting a high spatial dependence (Table 3 and Figure 5).

The decreasing ratio of the ranges (m) is as follows: DP2 (47.8), DS2 (30.6), UG1 (28.5), DS1 (27.0), DP1 (23.1) and UV1 (17.4) (Table 3). Therefore, in the conditions of the present research, the values of the ranges to be used in the geostatistical packages that will feed the computational packages used in precision forestry, in general, should not be smaller than $17.4 \mathrm{~m}$ when under Brazilian Cerrado conditions in a clayey Oxisol.

Analyzing the physical and chemical attributes of the soil, the lowest value for the correlation coefficient found was 0.021 for the DP1 and the highest value of 0.201 was observed for DP2 (Table 3). The low coefficients of correlation are due to the dispersion of the cloud of points around the ideal line, which has an angular coefficient of 1 and cuts the origin of the y-axis (intercept) in the zero value. Thus, from the point of view of the geostatistical analysis, the DP2 was the attribute that presented as plausible quality indicator, in this case, soil physics with angular coefficient (b) of the cross validation of 0.815 (Table 4).

Table 3. Spatial analysis of some components of eucalyptus production and attributes of an Oxisol

\begin{tabular}{llllllllll}
\hline Attribute & Co & Co+C & Model & A & SQResidual & $\mathbf{R}^{2}$ & ADE (\%) & DAL & IU \\
\hline ALT & $1.726^{*} 10$ & $1.726^{*} 10$ & EPP & - & - & - & - & 68.30 & 9 \\
DAP & 8.530 & 8.530 & EPP & - & - & - & - & 68.30 & 9 \\
DP1 & $1.980 * 10^{-3}$ & $1.946 * 10^{-2}$ & Exponential & 23.1 & $1.280 * 10^{-5}$ & 0.509 & 89.8 & 68.30 & 9 \\
DP2 & $3.769 * 10^{-3}$ & 0.011420 & Spherical & 47.8 & $3.866 * 10^{-6}$ & 0.855 & 67.1 & 68.30 & 9 \\
DS1 & $2.000 * 10^{-3}$ & $1.38^{*} 10^{-2}$ & Exponential & 27.0 & $3.983 * 10^{-5}$ & 0.215 & 85.5 & 85.38 & 9 \\
DS2 & $2.580 * 10^{-3}$ & $1.456 * 10^{-2}$ & Exponential & 30.6 & $6.922 * 10^{-6}$ & 0.634 & 82.3 & 68.30 & 9 \\
RP1 & 5.970 & 5.970 & EPP & - & - & - & - & 68.30 & 9 \\
RP2 & 9.539 & 9.539 & EPP & - & - & - & - & 68.30 & 9 \\
UV1 & $6.5 * 10^{-5}$ & $5.12 * 10^{-4}$ & Exponential & 17.4 & $2.782 * 10^{-8}$ & 0.121 & 87.3 & 68.30 & 9 \\
UV2 & $2.740 * 10^{-4}$ & $2.740 * 10^{-4}$ & EPP & - & - & - & - & 68.30 & 9 \\
UG1 & $1.200 * 10^{-5}$ & $9.100^{*} 10^{-5}$ & Exponential & 28.5 & $4.729 * 10^{-10}$ & 0.507 & 86.8 & 68.30 & 9 \\
UG2 & $5.3 * 10^{-5}$ & $5.300 * 10^{-5}$ & EPP & - & - & - & - & 68.30 & 9 \\
PT1 & $3.740 * 10^{-3}$ & $3.740 * 10^{-3}$ & EPP & - & - & - & - & 68.30 & 9 \\
PT2 & $2.175 * 10^{-3}$ & $2.175 * 10^{-3}$ & EPP & - & - & - & - & 68.30 & 9 \\
MO1 & $2.957 * 10$ & $2.957 * 10$ & EPP & - & - & - & - & 68.30 & 9 \\
MO2 & 3.756 & 3.756 & EPP & - & - & - & - & 68.30 & 9 \\
PH1 & $7.933^{*} 10^{-2}$ & $7.933 * 10^{-2}$ & EPP & - & - & - & - & 68.30 & 9 \\
PH2 & $2.216^{*} 10^{-2}$ & $2.216^{*} 10^{-2}$ & EPP & - & - & - & - & 68.30 & 9 \\
ACPOT1 & $3.556^{*} 10^{-2}$ & $3.556 * 10^{-2}$ & EPP & - & - & - & - & 68.30 & 9 \\
ACPOT2 & $1.045^{*} 10^{-2}$ & $1.045^{*} 10^{-2}$ & EPP & - & - & - & - & 68.30 & 9 \\
\hline
\end{tabular}

Note. ${ }^{(a)}$ ALT $=$ Eucalyptus plant height; DAP $=$ Diameter at breast height; RP, UG, UV, DS, DP, PT, MO, $\mathrm{pH}$ and ACPOT 1 and 2, are respectively the penetration resistance, gravimetric humidity, volumetric humidity, soil density, particle density, total porosity, organic matter, hydrogen potential and acidity potential, collected in the soil layers; $\mathrm{EPP}=$ nugget effect; $\mathrm{ADE}=$ space dependency assessor. 
Table 4. Cross-validation of spatial analysis of some components of eucalyptus production and attributes of an Oxisol

\begin{tabular}{lllll}
\hline \multirow{2}{*}{ Attribute } & \multicolumn{3}{c}{ Cross-validation } & Eliminated Points \\
\cline { 2 - 4 } & $\mathbf{R C}=\mathbf{b}$ & $\mathbf{Y = a}$ & $\mathbf{R}^{\mathbf{2}}$ & $(1) \rightarrow$ point 3 \\
DP1 & 0.420 & 1.52 & 0.021 & $(1) \rightarrow$ point 9 \\
DP2 & 0.815 & 0.48 & 0.201 & $(2) \rightarrow$ points 7 and 18 \\
DS1 & -0.503 & 1.74 & 0.032 & $(2) \rightarrow$ points 16 and 23 \\
DS2 & 0.955 & 0.06 & 0.179 & $(1) \rightarrow$ point 38 \\
UG1 & 0.441 & 0.07 & 0.042 & $(2) \rightarrow$ points 4 and 30 \\
UV1 & -0.770 & 0.25 & 0.034 & D
\end{tabular}

Note. ${ }^{(\mathrm{a})} \mathrm{ALT}=$ Eucalyptus plant height; DAP $=$ Diameter at breast height; RP, UG, UV, DS, DP, PT, MO, pH and ACPOT 1 and 2, are respectively the penetration resistance, gravimetric humidity, volumetric humidity, soil density, particle density, total porosity, organic matter, hydrogen potential and acidity potential, collected in the soil layers; $\mathrm{RC}=$ regression coefficient, $\mathrm{a}=$ angular coefficient.

In relation to the kriging maps (Figure 6), a spatial distribution arrangement of well-defined physical attributes can be observed in the evaluated area, which allowed the identification of homogeneous and soil-specific zones, which are very distinct for most of the attributes of plants and chemicals studied. It was found that the maps with high spatial similarity for the practical effect of soil management were those of DP1 (Figure 6A), DP2 (Figure 6B), DS1 (Figure 6C) and DS2 (Figure 6D). The relative similarities between these kriging maps occurred in the Center-South region, where the highest particle density concentrate $\left(>2.658->2.774 \mathrm{~kg} \mathrm{dm}^{-3}\right.$ and $>2.614->$ $\left.2.672 \mathrm{~kg} \mathrm{dm}^{-3}\right)$ and soil density $\left(>1.13->1.22 \mathrm{~kg} \mathrm{dm}^{-3}\right.$ and $\left.>1.23->1.32 \mathrm{~kg} \mathrm{dm}^{-3}\right)$ in $0.0-0.2$ and $0.2-0.4 \mathrm{~m}$ layers, respectively, indicating that possibly this region presents a tendency of greater soil compaction, demanding a different management from the physical point of view.

The isolines maps obtained by means of data interpolation, kriging method, are fundamental in precision forestry. These data are then analyzed and worked with the purpose of planning new samplings and performing more accurate soil management, with lower cost/benefit ratio, according to the spatial variability of the values of each evaluated attribute. 
A.

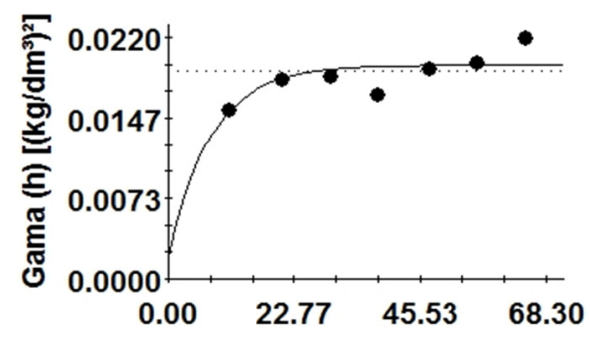

C.

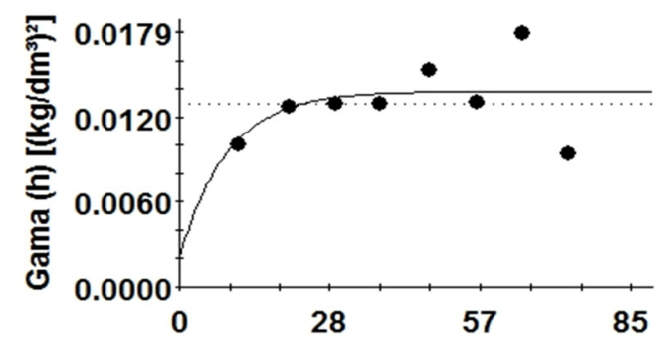

E.

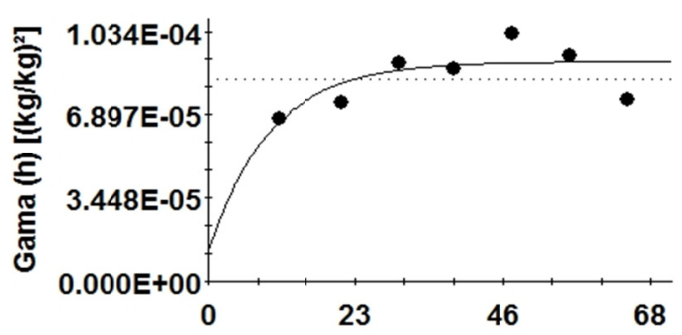

B.

DP2

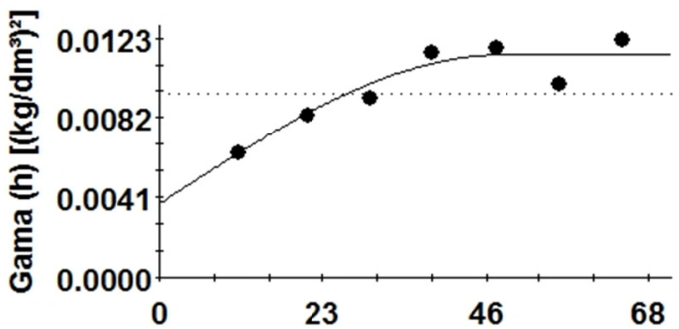

D. DS2

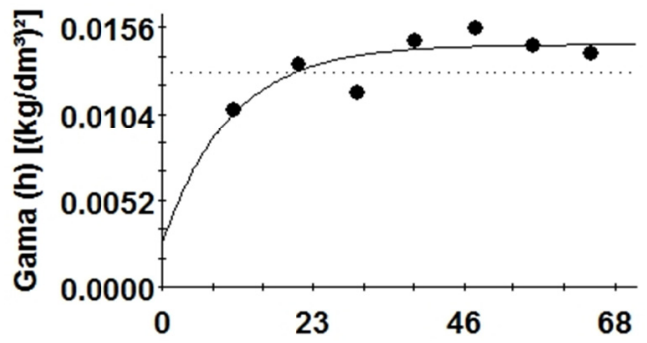

F.

UV1

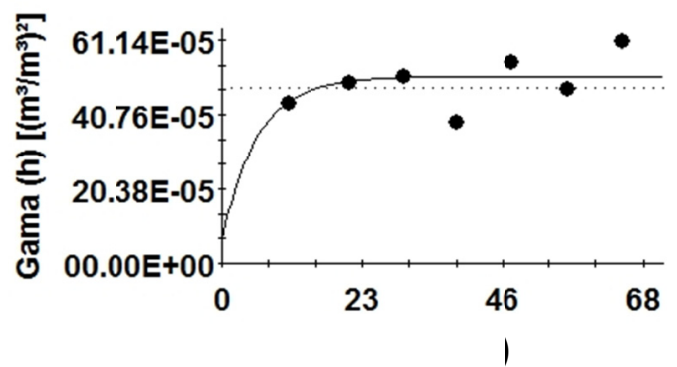

Figure 5. Semivariogram of a) Particle density in the layer 0-0.2 $\mathrm{m}\left(\mathrm{kg} \mathrm{dm}^{-3}\right)$; b) Particle density in the layer $0.2-0.4 \mathrm{~m}\left(\mathrm{~kg} \mathrm{dm}^{-3}\right)$; c) Soil density in the layer $0-0.2 \mathrm{~m}\left(\mathrm{~kg} \mathrm{dm}^{-3}\right)$; d) Soil density in the layer $0.2-0.4 \mathrm{~m}(\mathrm{~kg}$ $\left.\mathrm{dm}^{-3}\right)$; e) Gravimetric humidity in the layer $\left.0-0.2 \mathrm{~m}_{\left(\mathrm{kg} \mathrm{kg}^{-1}\right)}\right)$; and f) Volumetric humidity in the layer $0-0.2 \mathrm{~m}^{\left(\mathrm{m}^{3} \mathrm{~m}^{-3}\right)}$ 

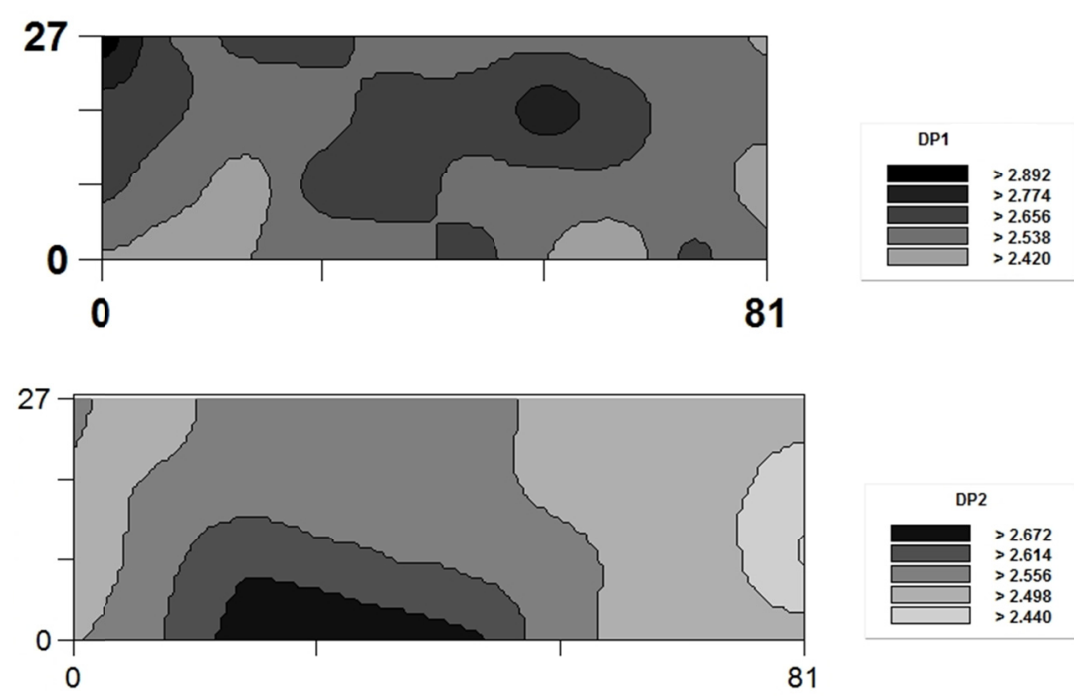

1.
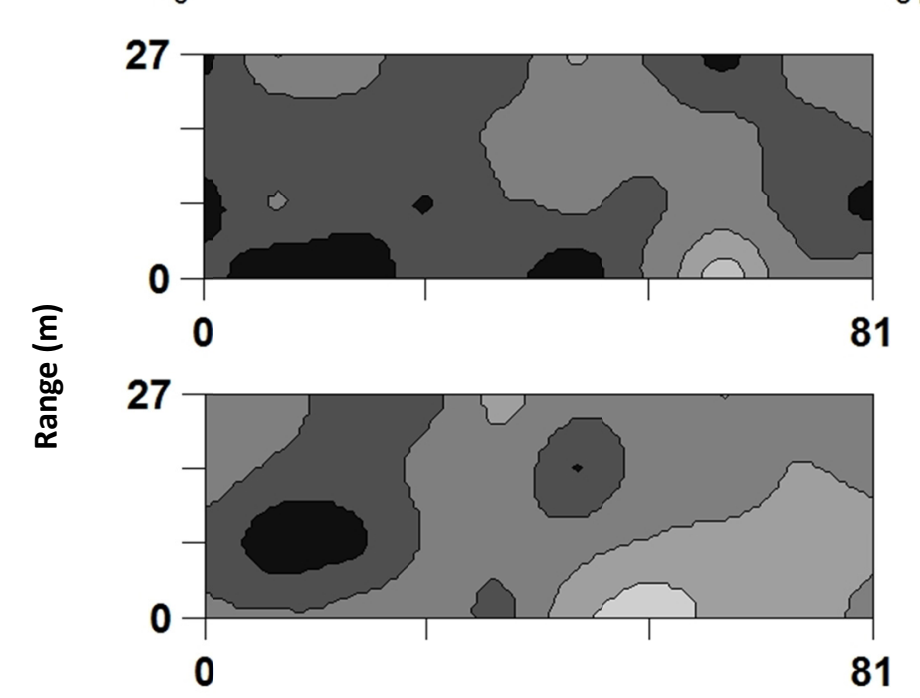

).
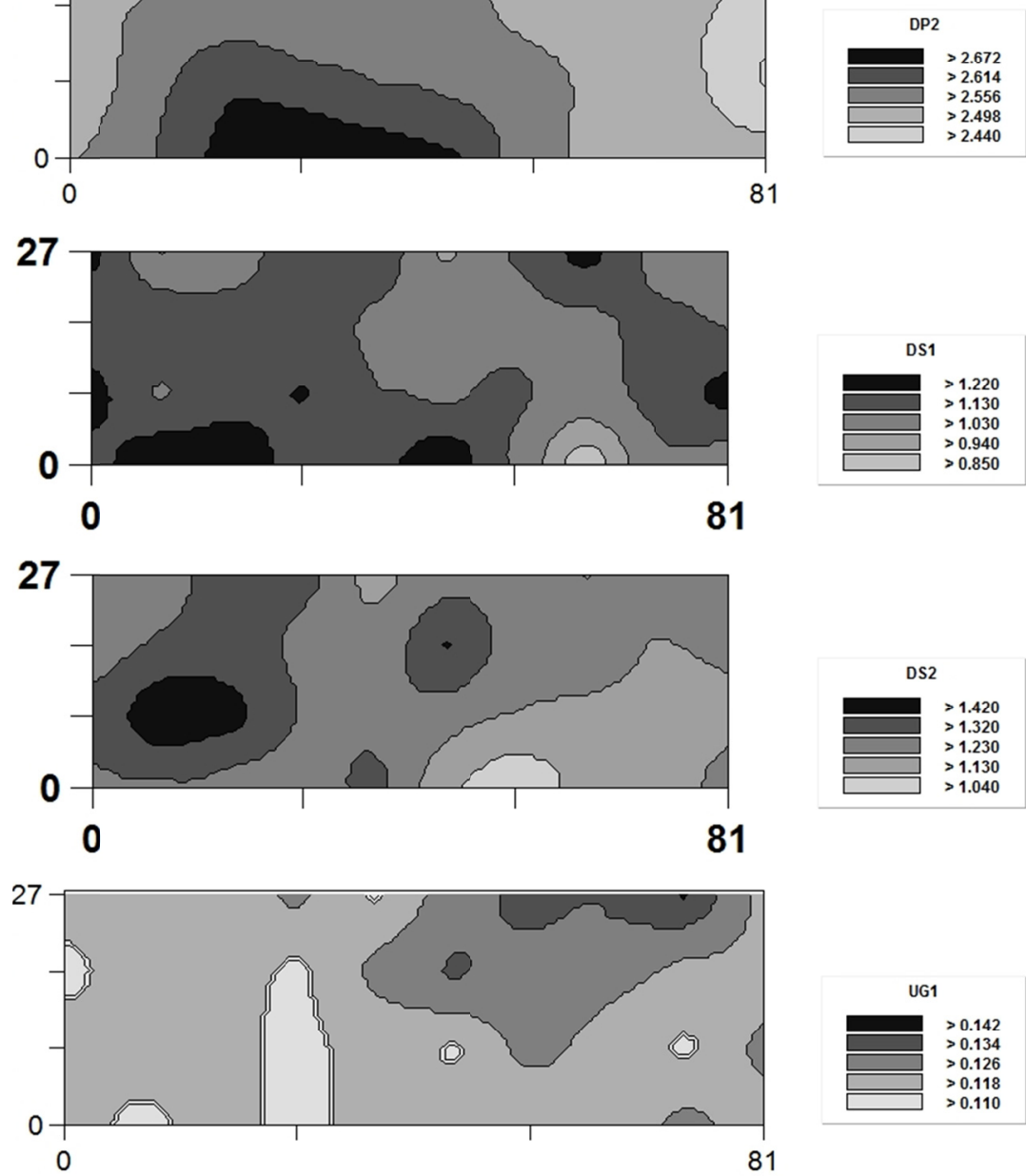

3.
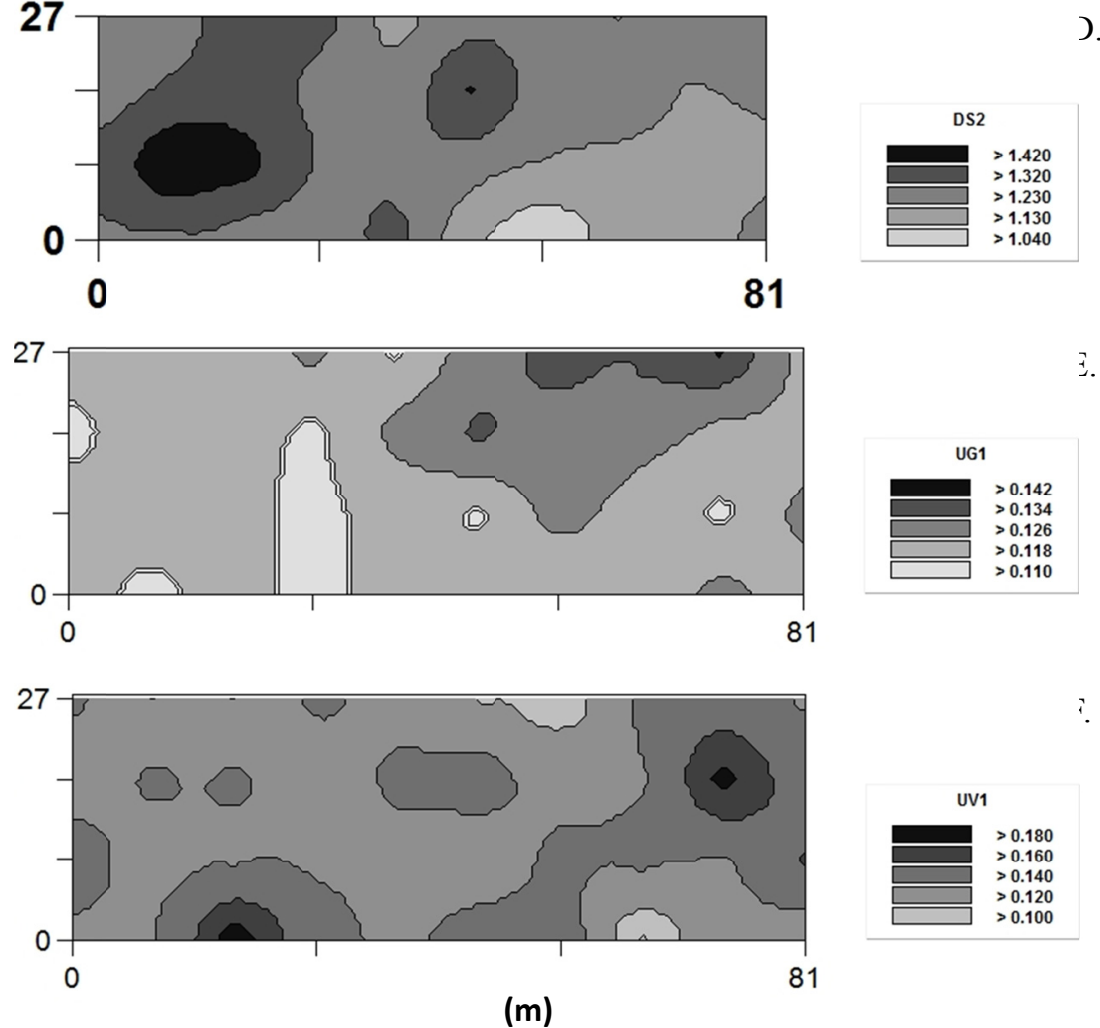

Figure 6. Kriging map of a) Particle density in the layer 0-0.2 $\mathrm{m}\left(\mathrm{kg} \mathrm{dm}^{-3}\right)$; b) Particle density in the layer 0.2-0.4 $\mathrm{m}\left(\mathrm{kg} \mathrm{dm}^{-3}\right)$; c) Soil density in the layer $0-0.2 \mathrm{~m}\left(\mathrm{~kg} \mathrm{dm}^{-3}\right)$; d) Soil density in the layer $\left.0.2-0.4 \mathrm{~m}\left(\mathrm{~kg} \mathrm{dm}^{-3}\right) ; \mathrm{e}\right)$ Gravimetric humidity in the layer $0-0.2 \mathrm{~m}\left(\mathrm{~kg} \mathrm{~kg}^{-1}\right)$; and f) Volumetric humidity in the layer $0-0.2 \mathrm{~m}^{\left(\mathrm{m}^{3} \mathrm{~m}^{-3}\right)}$ 


\section{Conclusions}

The plant attributes of Eucalyptus camaldulensis showed high variability, while for the soil physical and chemical attributes the variability was low and medium.

Spatially, the dendrometric attributes of Eucalyptus camaldulensis and soil chemical attributes showed pure nugget effect and the great majority of soil physical attributes presented spatial dependence, which varied according to the evaluated attribute and depth of collection. In addition to the vertical variability, there is also horizontal variability between depths, since for the same attribute the range was different between the sampled layers.

The Kriging maps allowed a visualization of the distribution of the soil physical attributes representing an important instrument to its management.

\section{References}

Anjos, R. A. M., \& Fonte, A. P. N. (2017). Rendimento de madeira serrada de espécies de Eucalyptus. Revista de Ciências Agroveterinárias, 16(1), 26-32. https://doi.org/10.5965/223811711612017026

Arshad, M. A., Lowery, B., \& Grossman, B. (1996). Physical tests for monitoring soil quality. In J. W. Doran, \& A. J. Jones (Eds.), Methods for assessing soil quality (SSSA Special Publication, 49, pp. 123-141). Madison: Soil Science Society of America.

Arthur, A. G., Oliveira, D. P., Costa, M. C. G., Romero, R. E., Silva, M. V. C., \& Ferreira, T. O. (2014). Variabilidade espacial dos atributos químicos do solo, associada ao microrrelevo. Revista Brasileira de Engenharia Agrícola e Ambiental, 18(2), 141-149. https://doi.org/10.1590/S1415-43662014000200003

Barbosa, C. E. M., Ferrari, S., Carvalho, M. P., Picolli, P. R. F., Cavallini, M. C., Benett, C. G. S., \& Santos, D. M. A. (2012). Inter-relação da produtividade de madeira do pinus com atributos físico-químicos de um Latossolo do Cerrado Brasileiro. Revista Árvore, 36(1), 25-35. https://doi.org/10.1590/S0100-67622012000 100004

Bottega, E. L., Queiroz, D. M., Pinto, F. A. C., \& Souza, C. M. A. (2013). Variabilidade espacial de atributos do solo em sistema de semeadura direta com rotação de culturas no Cerrado Brasileiro. Revista Ciência Agronômica, 44(1), 1-9. https://doi.org/10.1590/S1806-66902013000100001

Busscher, W. J., Bauer, P. J., Camp, C. R., \& Sojka, R. E. (1997). Correction of cone index for soil water content differences in a coastal plain soil. Soil and Tillage Research, 43, 205-217. https://doi.org/10.1016/ S0167-1987(97)00015-9

Camargo, O. A., \& Alleoni, L. R. F. (1997). Compactação do solo e o desenvolvimento das plantas (p. 132). Piracicaba, Escola Superior de Agricultura Luiz de Queiroz.

Carvalho, M. P., Mendonça, V. Z., Pereira, F. C. B. L., Arf, M. V., Kappes, C., \& Dalchiavon, F. C. (2012). Produtividade de madeira do eucalipto correlacionada com atributos do solo visando ao mapeamento de zonas específicas de manejo. Ciência Rural, 42(10), 1797-1903. https://doi.org/10.1590/S0103-847820 12005000078

Centurion, J. F. (1982). Balanço hídrico da região de Ilha Solteira. Científica, 10(1), 57-61.

Corá, J. E., Araujo, A. V., Pereira, G. T., \& Beraldo, J. M. G. (2004). Variabilidade espacial de atributos do solo para adoção do sistema de agricultura de precisão na cultura de cana-de-açúcar. Revista Brasileira de Ciência do Solo, 25(6), 1013-1021. https://doi.org/10.1590/S0100-06832004000600010

Costa, C. D. O., Alves, M. C., Sousa, A. P., \& Silva, H. R. (2015). Propriedades químicas dos solos de uma sub-bacia hidrográfica sob processo de degradação ambiental. Revista de Ciências Ambientais, 9(2), 37-50. https://doi.org/10.18316/1981-8858.15.10

Costa, P. A., Mota, J. C. A., Romero, R. E., Freire, A. G., \& Ferreira, T. O. (2014). Changes in soil pore network in response to twenty-three years of irrigation in a tropical semiarid pasture from northeast Brazil. Soil and Tillage Research, 137, 23-32. https://doi.org/10.1016/j.still.2013.11.004

Dalchiavon, F. C., Carvalho, M. P., Freddi, O. S., Andreotti, M., \& Montanari, R. (2011). Variabilidade espacial da produtividade do feijoeiro correlacionada com atributos químicos de um Latossolo Vermelho distroférrico sob sistema de semeadura direta. Bragantia, 70(4), 1-9. https://doi.org/10.1590/S0006-87052 011000400025 
Embrapa (Empresa Brasileira de Pesquisa Agropecuária). (1997). Manual de métodos de análise do solo (2nd ed., p. 212). Rio de Janeiro.

Figueiredo, C. C., Ramos, M. L. G., \& Tostes, R. (2008). Propriedades físicas e matéria orgânica de um Latossolo Vermelho sob sistemas de manejo e Cerrado nativo. Bioscience Journal, 24(3), 24-30.

Galindo, F. S., Teixeira Filho, M. C. M., Buzetti, S., Santini, J. M. K., Alves, C. J., Nogueira, L. M., ... Bellotte, J. L. M. (2016). Corn yield and foliar diagnosis affected by nitrogen fertilization and inoculation with Azospirillum brasilense. Revista Brasileira de Ciência do Solo, 40(1), e015036. https://doi.org/10.1590/ $18069657 \mathrm{rbcs} 20150364$

Robertson, G. P. (2004). GS $S^{+}$Geostatistics for environmental sciences (7th ed., p. 159). Plainwell, Gamma Desing Software.

Guimarães, E. C. (2004). Geoestatística básica e aplicada (p. 76). Uberlândia-MG: Universidade Federal de Uberlândia.

Lima, C. G. R., Carvalho, M. P., Narimatsu, K. C. P., Silva, M. G., \& Queiroz, H. A. (2010a). Atributos físico-químicos de um Latossolo do Cerrado Brasileiro e sua relação com características dendrométricas do eucalipto. Revista Brasileira de Ciência do Solo, 34(1), 163-173. https://doi.org/10.1590/S0100-0683201 0000100017

Lima, E. S., Montanari, R., Lovera, L. H., Teixeira Filho, M. C. M., \& González, A. P. (2017a). Variabilidade espacial das propriedades dendrométricas do eucalipto e atributos químicos de um Neossolo Quartzarênico. Revista de Agricultura Neotropical, 4(1), 1-11.

Lima, E. S., Montanari, R., Lovera, L. H., Teixeira Filho, M. C. M., Silva, V. E., \& Lima, C. G. R. (2017b). Spatial variability of eucalyptus and physical attributes of soil fertilized with lime mud and mineral fertilizer. Brazilian Journal of Agriculture, 92(2), 132-146.

Lima, E. S., Souza, Z. M., Montanari, R., Oliveira, S. R. M., Lovera, L. H., \& Farhate, C. V. V. (2017c). Classification of the initial development of Eucaliptus using data mining techniques. Cerne, 23(2), 201-208. https://doi.org/10.1590/01047760201723022296

Lima, J. S. S., Souza, G. S., \& Silva, S. A. (2010b). Amostragem e variabilidade espacial de atributos químicos do solo em área de vegetação natural em regeneração. Revista Árvore, 34(1), 127-136. https://doi.org/ 10.1590/S0100-67622010000100014

Lima, J. S. S., Souza, G. S., \& Silva, S. A. (2013). Distribuição espacial da matéria orgânica, grau de floculação e argila dispersa em água em área de vegetação natural em regeneração e pastagem. Revista Árvore, 37(3), 539-546. https://doi.org/10.1590/S0100-67622013000300017

Marasca, I., Oliveira, C. A. A., Guimarães, E. C., Cunha, J. P. A. R., Assis, R. L., Perin, A., \& Menezes, L. A. S. (2011). Variabilidade espacial da resistência do solo à penetração e teor de água em sistema de plantio direto, na cultura da soja. Bioscience Journal, 27(2), 239-246.

Marchini, D. C., Ling, T. C., Alves, M. C., Crestana, S., Souto Filho, S. N., \& Arruda, O. G. (2015). Matéria orgânica, infiltração e imagens tomográficas de Latossolo em recuperação sob diferentes tipos de manejo. Revista Brasileira de Engenharia Agrícola e Ambiental, 19(6), 574-580. https://doi.org/10.1590/ 1807-1929/agriambi.v19n6p574-580

Modolo, A. J., Fernandes, H. C., Schaefer, G. C. E., \& Silveira, J. C. M. (2008). Efeito da compactação do solo sobre a emergência de plântulas de soja em sistema plantio direto. Ciência e Agrotecnologia, 32(4), 1259-1265. https://doi.org/10.1590/S1413-70542008000400034

Pavinato, P. S., \& Rosolem, C. A. (2008). Disponibilidade de nutrientes no solo-decomposição e liberação de compostos orgânicos de resíduos vegetais. Revista Brasileira de Ciência do Solo, 32(3), 911-920. https://doi.org/10.1590/S0100-06832008000300001

Pelissari, A. L., Caldeira, S. F., Drescher, R., \& Santos, V. S. (2012). Modelagem geoestatística da dinâmica espacial da altura dominante de Tectona grandis L.f. (Teca). Enciclopédia Biosfera, 8(15), 1249-1260.

Pimentel-Gomes, F., \& Garcia, C. H. (2002). Estatística aplicada a experimentos agronômicos e florestais: Exposição com exemplos e orientações para uso de aplicativos (p. 309). Piracicaba, Fundação Escola de Agricultura Luiz de Queiroz. Piracicaba: Fealq.

Pulrolnik, K., Barros, N. F., Silva, I. R., Novais, R. F., \& Brandani, C. B. (2009). Estoques de carbono e nitrogênio em frações lábeis e estáveis da matéria orgânica de solos sob eucalipto, pastagem e Cerrado no 
vale do Jequitinhonha, MG. Revista Brasileira de Ciência do Solo, 33(5), 1125-1136. https://doi.org/ 10.1590/S0100-06832009000500006

Raij, B. van, Andrade, J. C., Cantarella, H., \& Quaggio, J. A. (2001). Análise química para avaliação da fertilidade de solos tropicais (p. 285). Campinas: Instituto Agronômico.

Raij, B. van, Cantarella, H., Quaggio, J. A., \& Furlani, A. M. C. (1997). Recomendações de Adubação e Calagem para o Estado de São Paulo (2nd ed. Rev. Ampl.). Boletim Técnico, 100 (p. 285). Campinas, Instituto Agronômico \& Fundação IAC.

Rosa Filho, G., Carvalho, M. P., Montanari, R., Silva, J. M., Siqueira, G. M., \& Zambianco, E. C. (2011). Variabilidade espacial de propriedades dendrométricas do eucalipto e de atributos físicos de um Latossolo Vermelho. Bragantia, 70(2), 439-446. https://doi.org/10.1590/S0006-87052011000200027

Santos, H. G., Jacomine, P. K. T., Oliveira, V. A., Lumbreras, J. F., Coelho, M. R., Almeida, J. A., ... Oliveira, J. B. (2013). Sistema brasileiro de classificação de solos (3rd ed., p. 353). Brasília: Embrapa.

Schlotzhaver, S. D., \& Littell, R. C. (1997). SAS system for elementary statical analysis (2nd ed., p. 441). Cary.

SFB (Serviço Florestal Brasileiro). (2016). As florestas plantadas. Brasília-DF: SFB. Retrieved May 12, 2016 , from http://www.florestal.gov.br/snif/recursos-florestais/estoque-das-florestas

Shapiro, S. S., \& Wilk, M. B. (1965). An analysys of variance test for normality: Complete samples. Biometrika, 52(3/4), 591-611. https://doi.org/10.2307/2333709

Silva, A. M., Canuto, D. S. O., Alves, M. C., Buzetti, S., Moraes, M. L. T., \& Sakamoto, A. Y. (2016). Características químicas de um Latossolo Vermelho em recuperação sob plantio de Pinus spp. Ciência Florestal, 26(4), 1049-1060. https://doi.org/10.5902/1980509824994

Silva, A. S., Silva, I. F., Bandeira, L. B., Dias, B. O., \& Silva Neto, L. F. (2014). Argila e matéria orgânica e seus efeitos na agregação em diferentes usos do solo. Ciência Rural, 44(10), 1783-1789. https://doi.org/10.1590/ 0103-8478cr20130789

Silva, E. A. A., Uribe-Opazo, M. A., Rocha, J. V., \& Souza, E. G. (2003). Um Estimador robusto e o semivariograma cruzado na ánalise de variabilidade espacial de atributos do solo e planta. Acta Scientiarum. Agronomy, 25(2), 365-371. https://doi.org/10.4025/actasciagron.v25i2.1984

Silva, J. E., \& Resck, D. V. S. (1997). Matéria orgânica do solo. In M. A. T. Vargas, \& M. Hungria (Ed.), Biologia dos solos dos cerrados (pp. 467-524). Planaltina: Embrapa-CPAC.

Silva, S. A., Lima, J. S. S., Souza, G. S., Oliveira, R. B., \& Silva, A. F. (2010). Variabilidade espacial do fósforo e das frações granulométricas de um Latossolo Vermelho Amarelo. Revista Ciência Agronômica, 41(1), 1-8.

Silveira, D. C., Melo Filho, J. F., Sacramento, J. A. A. S., \& Silveira, E. C. P. (2010). Relação umidade versus resistência à penetração para um Argissolo Amarelo distrocoeso no recôncavo da Bahia. Revista Brasileira de Ciência do Solo, 34(3), 659-667. https://doi.org/10.1590/S0100-06832010000300007

Simões, J. W., Coelho, A. S. R., Mello, H. A., \& Couto, H. T. Z. (1980). Crescimento e produção de madeira de eucalipto. IPEF, 20, 77-97.

Souza, Z. M., Campos, M. C. C., Cavalcante, I. H. L., Marques Júnior, J., Cesarin, L. G., \& Souza, S. R. (2006). Dependência espacial da resistência do solo à penetração e teor de água do solo sob cultivo de cana-de-açúcar. Ciência Rural, 36(1), 128-134. https://doi.org/10.1590/S0103-84782006000100019.

Stolf, R. (1991). Teoria e teste experimental de fórmulas de transformação dos dados de penetrômetro de impacto em resistência do solo. Revista Brasileira de Ciência do Solo, 15(3), 229-235.

Stone, L. F., Guimarães, C. M., \& Moreira, J. A. A. (2002). Compactação do solo na cultura do feijoeiro-1: Efeitos nas propriedades físico-hídricas do solo. Revista Brasileira de Engenharia Agrícola e Ambiental, 6(2), 207-12. https://doi.org/10.1590/S1415-43662002000200004

Toledo, F. H. S. F., Venturin, N., Carlos, L., Dias, B. A. S., Venturin, R. P., \& Macedo, R. L. G. (2015). Composto de resíduos da fabricação de papel e celulose na produção de mudas de eucalipto. Revista Brasileira de Engenharia Agrícola e Ambiental, 19(7), 711-716. https://doi.org/10.1590/1807-1929/ agriambi.v19n7p711-716.

Vieira, S. R. (2000). Geoestatística em estudos de variabilidade especial do solo. In R. F. Novais, V. H. Alvarez, \& C. E. G. R. Schaefer (Eds.), Tópicos em ciência do solo (Vol. 1, pp. 1-53). Viçosa-MG: SBCS. 
Wendling, B., Vinhal-Freitas, I. C., Oliveira, R. C., Babata, M. M., \& Borges, E. N. (2012). Densidade, agregação e porosidade do solo em áreas de conversão do cerrado em floresta de pinus, pastagem e plantio direto. Bioscience Journal, 28(Suppl. 1), 256-265.

\section{Copyrights}

Copyright for this article is retained by the author(s), with first publication rights granted to the journal.

This is an open-access article distributed under the terms and conditions of the Creative Commons Attribution license (http://creativecommons.org/licenses/by/4.0/). 